\title{
KETERCAPAIAN HASIL BELAJAR SISWA SMK PADA PRAKTIK PEMELIHARAAN AC SPLIT
}

\author{
Pandu $^{1}$, Wahid Munawar ${ }^{2}$, Ega T. Berman ${ }^{3}$ \\ Departemen Pendidikan Teknik Mesin \\ Universitas Pendidikan Indonesia \\ Jl. Dr. Setiabudhi No. 207 Bandung 40154 \\ pandutm09@gmail.com
}

\begin{abstract}
ABSTRAK
Tujuan penelitian ini adalah untuk memperoleh hasil belajar praktik pemeliharaan AC split siswa SMK ditinjau dari proses kerja ,hasil kerja dan ketercapaian waktu. Penelitian ini menggunakan metode eksperimen dengan pendekatan kuantitatif. Desain penelitian yang digunakan adalah one shot case study dimana peneliti memberikan perlakuan kepada sejumlah objek penelitian dan kemudian dianalisis hasilnya yang diperoleh berdasarkan pengamatan. Hasil penelitian ini menunjukkan ketercapaian siswa pada praktik pemeliharaan AC split dilihat dari proses kerja dan hasil kerja telah sesuai dengan standar industri. Hasil belajar peserta didik dilihat dari langkah kerja, hasil kerja dan ketercapaian waktu menunjukkan nilai rata-rata keseluruhan peserta didik adalah 63 dengan hasil dua orang peserta didik tidak tercapai dan empat orang lainnya tercapai.
\end{abstract}

Kata kunci: waktu, capaian, hasil belajar, pemeliharaan

\section{PENDAHULUAN}

Kompetensi lulusan pendidikan kejuruan sebagai subsistem dari sistem pendidikan nasional. Penghasil tamatan yang memiliki keterampilan dan penguasaan IPTEK dengan bidang dari tingkat keahlian yang sesuai dengan kebutuhan pembangunan, penghasil tamatan yang memiliki kemampuan produktif, penghasil sendiri, mengubah status tamatan dari status beban menjadi aset bangsa yang mandiri, penghasil penggerak perkembangna industri Indonesia yang kompetitif menghadapi pasar global (Dit PSMP, 2013). Pernyataan tersebut menjelaskan bahwa siswa lulusan SMK harus memiliki life skill yang cukup untuk dapat bersaing di dunia uasaha dan industri agar dapat bekerja dan memenuhi tujuan tersebut.

Kenyataan yang terjadi saat ini masih terdapat lulusan SMK yang tidak bekerja atau mengalami pengangguran. Pada umumnya perusahaan enggan menerima lulusan SMK bukan karena menghapus kuota lulusan SMK untuk bekerja di perusahaannya, akan tetapi hal tersebut lebih dikarenakan kualitas lulusan SMK yang masih buruk ketika bekerja (Melisa, 2013). Hasil observasi menyatakan bahwa 67,5 \% siswa jurusan teknik pendingin di SMK negeri yang terdapat di kecamatan Cihampelas mengalami kegagalan pada mata pelajaran tersebut. Proses pembelajaran yang diterapkan pada matapelajaran PMRT selama ini

\footnotetext{
${ }^{1}$ Mahasiswa Departemen Pendidikan Teknik Mesin FPTK UPI

2 Dosen Departemen Pendidikan Teknik Mesin FPTK UPI

${ }^{3}$ Dosen Departemen Pendidikan Teknik Mesin FPTK UPI
} 
menggunakan metode ceramah yang cenderung monoton sehingga siswa kurang termotivasi dalam mengikuti proses pelaksanaan pembelajaran. Penilaian tersebut dilakukan dengan melihat dari unjuk kerja siswa maupun ketercapaian waktu siswa pada saat melaksanakan ujian praktikum.

Permasalahan tersebut dapat ditanggulangi dengan memperbaiki kualitas pembelajaran dan penilaian. Usaha peningkatan kualitas pendidikan dapat ditempuh melalui peningkatan kualitas pembelajaran dan kualitas sistem penilaian. Keduanya saling terkait, sistem pembelajaran yang baik akan menghasilkan kualitas belajar yang baik (Mardapi, 2003). Selanjutnya sistem penilaian yang baik akan mendorong guru untuk menentukan strategi mengajar yang baik dan memotivasi siswa untuk belajar lebih baik.

Pembelajaran praktik merupakan suatu proses untuk meningkatkan keterampilan peserta didik dengan menggunakan berbagai metode yang sesuai dengan keterampilan yang diberikan dan peralatan yang digunakan. Selain itu, pembelajaran praktik merupakan suatu proses pendidikan yang berfungsi membimbing peserta didik secara sistematis dan terarah untuk dapat melakukan suatu keterampilan. Pembelajaran praktik dapat meningkatkan kemampuan peserta didik dalam mengaplikasikan pengetahuan dan keterampilan yang diperolehnya. Kegiatan ini dilakukan di lapangan, yang bisa berarti di tempat kerja, maupun di masyarakat. Praktik merupakan upaya untuk memberi kesempatan kepada peserta didik untuk mendapatkan pengalaman langsung (Juono, 2013). Ide dasar belajar berdasarkan pengalaman mendorong peserta didik untuk merefleksi atau melihat kembali pengalamanpengalaman yang mereka pernah alami.

Langkah-langkah metode pembelajaran praktik tidak berbeda jauh dari langkahlangkah metode pembelajaran konvensional yang sudah banyak diterapkan dalam praktik pendidikan. Perbedaannya terletak pada masalah teknis yang disebabkan oleh obyek dan ruang lingkup pelaksanaan yang berbeda. Langkah-langkah pembelajaran praktik meliputi; perencanaan, pelaksanaan dan evaluasi.

\section{METODE PENELITIAN}

Penelitian ini menggunakan jenis eksperimen one shot case study, yakni peneliti memberikan perlakuan kepada sekolompok subjek tertentu yang kemudian dilakukan pengukuran untuk mengetahui sejauhmana perlakuan tersebut berdampak pada subjek penelitian. Penelitian eksperimen bertujuan untuk mencari sebab akibat (hubungan kausal) 
antar dua faktor yang sengaja ditimbulkan oleh peneliti dengan mengurangi faktor lain yang menggangu. Penelitian pre experimen jenis one shot case study merupakan desain penelitian dimana peneliti hanya melakukan satu kali treatment yang diperkirakan sudah mempunyai pengaruh untuk kemudian diadakan post-test.

Sampel pada penelitian ini berjumlah 6 orang yang merupakan peserta didik kelas XTPTU SMK Negeri 1 Cihampelas yang dipilih berdasarkan nilai yang diperolehnya selama di kelas, meliputi peringkat teratas ( 2 orang), menengah ( 2 orang), dan terbawah ( 2 orang). Instrumen yang digunakan untuk mengumpulkan data tentang hasil belajar keterampilan dasar teknik pendingin dalam bidang pemeliharaan AC split adalah berupa format yang disusun berisi penilaian langkah kerja tentang prosedur pemeliharaan AC Split. Instrumen kesesuaian waktu untuk menghitung ketercapaian waktu peserta didik pada setiap fase pelaksanaan pekerjaan (praktik) yang telah ditentukan standar waktunya.

\section{HASIL PENELITIAN}

Hasil pengamatan yang dilakukan selama 4 kali percobaan (praktik) menunjukkan pencapaian waktu yang dibutuhkan peserta didik untuk menyelesaikan seluruh pekerjaan dalam satu fase eksperimen. Seluruh peserta didik mengalami peningkatan dalam setiap fase eksperimen, namun pada fase eksperimen ke satu dan kedua seluruh peserta didik tidak dapat menyelesaikan perkerjaan sesuai dengan standar waktu yang ditentukan. Data yang telah diperoleh kemudian dikonversikan kedalam bentuk nilai dengan bobot $10 \%$ nilai untuk persiapan keselamatan kerja 10\% nilai untuk persiapan alat dan bahan kerja, $40 \%$ untuk langkah kerja dan $40 \%$ untuk nilai hasil kerja. Penilaian didapatkan dari hasil keterlaksanaan langkah kerja dan langkah kerja yang diperoleh. jika langkah kerja dan waktu pekerjaan telah sesuai maka mendapatkan skor satu, jika tidak tercapai salah satu atau keduanya maka mendapatkan skor nol.

Peserta didik 1 memperoleh waktu paling lambat pada fase eksperimen pertama dengan waktu 2.718 detik sedangkan yang tercepat pada fase eksperimen pertama adalah peserta didik 2.585 detik. Penyebab terjadinya keterlambatan waktu yang cukup tinggi adalah karena terjadi masalah dalam penggunaan pompa pembersih air, serta masalah lain yang timbul karena kurangnya pengalaman dari peserta didik itu sendiri. Fase eksperimen kedua memperlihatkan perkembangan yang cukup signifikan dari peserta didik 1 , terlihat kali ini peserta didik 5 menjadi yang paling lambat dengan waktu 2.466 detik sedangkan yang 
tercepat adalah peserta didik 2 dengan waktu 2.404 detik. Hasil eksperimen terakhir menunjukkan seluruh peserta didik mampu menyelesaikan pekerjaan lebih baik dibandingkan dengan standar yaitu 2.400 detik. Peserta didik 6 menjadi yang tercepat dengan waktu 2.256 sedangkan peserta didik 1 menjadi yang terlambat dengan waktu 2.290 detik. Data yang telah didapatkan kemudian dikonversi menjadi nilai dengan hasil (Tabel 1).

Tabel 1. Hasil Belajar Peserta Didik

\begin{tabular}{lcc}
\hline \multicolumn{1}{c}{ Keterangan } & Nilai & Keterangan \\
\hline Peserta didik 1 & 33 & Belum Tercapai \\
Peserta didik 2 & 75.3 & Tercapai \\
Peserta didik 3 & 75.3 & Tercapai \\
Peserta didik 4 & 79.5 & Tercapai \\
Peserta didik 5 & 39.5 & Belum Tercapai \\
Peserta didik 6 & 77.4 & Tercapai \\
Rata-rata & 63 & - \\
\hline
\end{tabular}

\section{PEMBAHASAN}

Pencapaian waktu peserta didik pada tahap persiapan keselamatan kerja tidak mengalami masalah, seluruh peserta didik dapat menyelesaikan lebih cepat dari standar waktu yang ditentukan. Pencapaian waktu peserta didik pada tahap persiapan alat dan bahan kerja kurang memuaskan karena seluruh peserta didik tidak dapat menyelesaikan pekerjaan sesuai dengan standar waktu yang ditentukan. Kondisi tersebut diakibatkan karena alat dan bahan yang akan disiapkan berserakan, sehingga peserta didik kesulitan untuk mengatur barang yang harus disiapkan pada awal kegiatan praktikum (Sudjana, 2005).

Rata-rata waktu peserta didik yang sudah sesuai dengan standar waktu yang ditentukan adalah langkah kerja persiapan keselamatan kerja, menutup seluruh komponen listrik outdoor unit, mengeringkan outdoor unit dengan menggunakan lap kering, membuka penutup indoor unit tanpa mengalami kerusakan, melepaskan saringan udara dari indoor unit, mengeringkan indoor unit dengan menggunakan lap kering, memasang kembali saringan indoor unit, menutup penutup pada indoor unit, memeriksa kesesuaian tekanan pada unit dengan tekanan yang tercantum pada keterangan, memeriksa kesesuaian arus listrik pada AC split dengan keterangan yang tercantum pada AC split.

Rata-rata waktu peserta didik pada langkah kerja membuka penutup outdoor unit kurang memuaskan. Peserta didik 4 memiliki rata-rata waktu sesuai dengan standar yang 
ditentukan, namun peserta lainnya memiliki rata-rata waktu yang belum sesuai dengan standar waktu yang ditentukan. Permasalahan tersebut terjadi karena peserta didik kesulitan melepaskan pengancing pada proses membuka penutup outdoor unit. Hal yang sama terjadi pada proses kerja membersihkan kondensor dengan menggunakan pompa pembersih, dimana hanya ada satu peserta didik yang memiliki rata-rata waktu sesuai dengan standar waktu yang ditentukan yaitu peserta didik 2. Kesulitan yang terjadi pada langkah kerja membersihkan kondenser dengan pompa pembersih adalah ketika pengoprasian pompa yang cukup menghabiskan banyak waktu karena seluruh peserta didik sebelumnya belum pernah mendapatkan pengalaman dalam mengoperasikan pompa. Rata-rata waktu kerja memasang manifold gauge pada katup servis memiliki hasil yang sama. Peserta didik yang memiliki ratarata waktu yang sesuai dengan standar yang diharapkan adalah peserta didik 4. Langkah kerja menutup outdoor unit seperti posisi semula memiliki hasil yang lebih baik dengan peserta didik 3, 4, 5 dan 6 memiliki rata-rata waktu yang telah sesuai dengan standar waktu yang ditentukan, sedangkan untuk langkah kerja membersihkan saringan indoor unit dari kotoran dan debu hanya peserta didik 1 yang memiliki rata-rata waktu tidak sesuai dengan standar yang ditentukan.

Rata-rata waktu yang sangat mencolok terlihat pada langkah kerja memasang plastik pengalir air pada AC split. Peserta didik mengalami kesulitan pada proses kerja tersebut karena plastik yang digunakan tidak seperti plastik yang pada umumnya, sehingga perlu latihan agar dapat memasangnya dengan benar. Langkah kerja berikutnya yang memiliki hasil yang sama adalah langkah kerja membersihkan indoor unit dan sirip-sirip pada evaporator dari kotoran dan debu yang menempel. Kesulitan yang terjadi pada langkah kerja tersebut terletak pada saat proses penggunaan pompa dengan tekanan tinggi karena harus dilaksanakan dengan hati-hati agar air tidak mengenai bagian lain selain sirip-sirp pada indoor unit. Hal yang sama terjadi pada proses pemasangan tang ampere dimana peserta didik kesulitan ketika menentukan kabel mana yang harus dipasangkan tang ampere.

Rata-rata waktu dari seluruh pekerjaan yang dilakukan oleh peserta didik memperlihatkan bahwa terdapat dua orang peserta didik yang memiliki rata-rata waktu belum sesuai dengan standar waktu yang ditentukan. Hasil tersebut merupakan perolehan waktu berdasarkan rata-rata waktu dari praktik pertama hingga praktik terakhir, namun bila dilihat pada hasil eksperimen terakhir peserta didik menunjukkan seluruh peserta didik 
mampu melaksanakan pemeliharaan $\mathrm{AC}$ split sesuai dengan standar yang ditentukan seperti diperlihatkan pada lampiran tabel waktu kerja intervensi.

Berdasarkan hasil pengamatan pada saat pelaksanaan praktik peserta didik mampu menyelesaikan pekerjaan sesuai dengan standar langkah kerja dan standar waktu setelah melaksanakan 3 kali percobaan. Hal tersebut membuktikan bahwa intervensi yang terkait dengan perubahan perilaku misalnya penguasaan keterampilan motorik tertentu mungkin membutuhkan intervensi yang panjang (Sunanto, 2005).

\section{KESIMPULAN}

Kesimpulan yang diperoleh pada penelitan ini menunjukkan bahwa hasil belajar siswa ditinjau dari unjuk kerja dan hasil belajar peserta didik telah sesuai dengan standar kompetensi di industri. Adapun hasil belajar peserta didik dilihat dari segi langkah kerja, hasil kerja dan ketercapaian waktu menunjukkan nilai rata-rata keseluruhan peserta didik adalah 63 dengan dua orang peserta didik dinyatakan tidak tercapai dan empat orang lainnya tercapai.

\section{DAFTAR PUSTAKA}

Direktorat Pembinaan Sekolah Menengah Kejuruan. (2013). Visi Misi dan Tujuan SMK [online] Tersedia: ditpsmk.net/?page=content;3. [25 Juni 2013].

Juono, R.F. (2013). Metode Pembelajaran. [Online]. Tersedia: http://juonorp.blogspot. com/2013/05/metode-pembelajaran.html. Diakses 25 Maret 2014.

Mardapi, Djemari. (2003). Pola Induk Sistem Pengujian Hasil KBM Berbasis Kemampuan Dasar, Jakarta: Rineka Cipta.

Melisa, F. (2013, 12 November). Lulusan SMK Sulit Bersaing. Republika. [Online]. halaman 5. Tersedia: http://acdpindonesia.files.wordpress.com [12 November 2013].

Sunanto, J. (2005). Pengantar penelitian dengan subyek tunggal. Bandung: Universitas Pendidikan Indonesia.

Sudjana, Nana. (2005). Dasar-Dasar Proses Belajar Mengajar. Bandung: Sinar Baru Algesindo. 